\title{
Bioactive Compounds in Herbal Bitter Drinks and Effects on selected Hepatic Biomarkers in Albino Wister Rats in Lagos, Nigeria
}

\author{
${ }^{* 1}$ OJEKALE, AB; ${ }^{2}$ LAWAL, O; ${ }^{1}$ LASISI, MO; ${ }^{1}$ BAMGBOSE, CA; ${ }^{1}$ DOSU, FA \\ ${ }^{1}$ Department of Biochemistry, ${ }^{2}$ Department of Chemistry, Lagos State University, Ojo, Lagos, Nigeria. \\ *Corresponding Author Email: anthony.ojekale@lasu.edu.ng
}

\begin{abstract}
Recently in Nigeria, the use of natural products described as herbal bitter drinks presumed to cure all except death has been on the increase. This paper therefore evaluates the bioactive compounds of three herbal drinks and their concomitant effects on selected hepatic biomarkers in albino Wister rats in Lagos, Nigeria using standard methods. A total of 31 bioactive compounds were positively identified in the three bitter drinks analyzed, Out of which are: Yoyo ( 5-Hydroxymethylfurfural (6.8\%), Coumaran (1.7\%), Octamethyl cyclotetrasiloxane ( $4.5 \%)$, Squalene(3.2\%) - 2,4Dihydroxy-2,5-dimethyl-3(2H)-furan-3-one(1.7\%),3,3-Dimethyl-2butanol(1.1\%),2-Hydroxy-2- cyclopenten-1-one $(0.7 \%)$ ). Swedish (Camphor (82.9\%), Cinnamic acid (0.2\%)). Living (5-Hydroxymethylfurfural 57.4\%), Coumaran (1.6\%), 3, 4-dihydroxy-3-cyclobutene-1, 2-dione ( $0.3 \%)$. The three bitters had no common bioactive compound between them. Five common bioactive compounds were detected present in both Living and Yoyo bitters. Only 11 (about 35\%) of the 31 compounds identified have established and documented pharmacological use. Some of the bioactive components in each of the bitters support the advertised usage of the formulations. The three bitters orally administered to rats from data gathered were not dangerous to the liver over the 40day period of the experiment.
\end{abstract}

DOI: https://dx.doi.org/10.4314/jasem.v23i12.9

Copyright: Copyright (C) 2019 Ojekale et al. This is an open access article distributed under the Creative Commons Attribution License (CCL), which permits unrestricted use, distribution, and reproduction in any medium, provided the original work is properly cited.

Dates: Received: 14 September 2019; Revised: 01 December 2019; Accepted: 20 December 2019

Keywords: Yoyo, Swedish, living, hepatic biomarkers

Most societies including Nigeria is admix of various religions, cultures and values. A common denominator amongst all is the belief in alternate or traditional or complementary medicine. Thus, a large percentage of the population use one form of alternate medicine or the other. The use of herbals is a common form of alternate medicine that cuts across all spectrum of the Nigerian society. This belief system has thrown up all sorts of alternate medical practitioners including but not limited to herbal practitioners, orthopaedics, etc. One of such fallouts is the large number of different types of herbal mixtures commonly sold in the different Nigerian markets as herbal mixtures (Akinyemi and Dada, 2014; Ogbonnia et al., 2010). Some of these commercial herbals (bitters inclusive) have specific therapeutic potentials; while others are marketed as a one mixture cures all. Some documented reports of bitters are as blood cleansers, detoxifiers, hypoglycaemic (Jimmy and Udofia, 2014; Oyevvo, 2013), immunomodulatory activities etc. Based on the "if its natural, it is safe" belief among people who consume herbal formulations, there is yet no government generated data in the public domain on the aetiology of the uprising cases of nephrotoxicity in Nigeria, of which the upsurge in herbals consumption may be contributory. Some natural herbals including bitters have been reported to be toxic(Ogbonnia et al., 2010; Oyevvo, 2013). This study aims at evaluating the bioactive compounds present in three herbal bitter drinks.

\section{MATERIALS AND METHODS}

Herbal sample collection: The three herbal bitters were purchased from a drug store in Lagos, Nigeria.

Table 1: Plant composition of the herbal bitters

\begin{tabular}{ll}
\hline \multicolumn{1}{c}{ Bitters } & \multicolumn{1}{c}{ Plant components } \\
\hline Swedish & Commiphora molmol, Cape aloe, Crocus sativus, Cassia angustifolia, Rheum palmatum, \\
& Curcuma zedoria, Bamboo manna,Theriaca venezian, Artemisia vulgaris, Angelica archangelica \\
Living & Aloe capensis, Hydrastis canadensis, Enchiacea angostifolia \\
Yoyo & Acinos arvensis, Citrus aurantifolla, Chenipodium murale, Cinamamum arromaticum, Aloe vera \\
\hline
\end{tabular}

Animals and Experimental Design: The animal earlier(Ojekale et al., 2008) using age matched experiment was conducted as described animals. The work was conducted under clearance 
from the University ethical committee. Two groups were used as control, viz: a group administered with distill water, and another group administered with $10 \%$ ethanol (being solvent base for bitters mixture).

Bioactive compositional analysis (GC-MS): The identification of bioactive compounds of Yoyo, Living and Swedish bitters were performed using a gas chromatograph-mass spectrograph as described earlier (Ojekale et al., 2016)

Liver function tests: ALT, AST, bilirubin levels were determined using test kits by Randox (United Kingdom).

Data Analysis: All data are expressed as means \pm error of mean $(\mathrm{x} \pm \mathrm{SEM})$. Data were analysed and plotted using MS Excel 2016 ®

\section{RESULTS AND DISCUSSIONS}

About 11 (about $35 \%$ ) of the 31 compounds identified have established and documented pharmacological use. The transaminases (AST and ALT) are biomarkers in monitoring compromised liver functioning and possibly hepatocellular damage.

The integrity of the liver was unchanged in the groups administered with Swedish and Living bitters, the converse is the case in the $10 \%$ ethanol and Yoyo bitters treated group. The concentrations of the assayed biomarkers (albumin, bilirubin, ALT and AST) were largely unaltered (Figures $1-4$ ) in the presence of Swedish bitters.

There is an observably increased blood ALT in the group administered with ALT, possibly generally suggesting a challenged liver function, but this increase is not considered physiologically important enough for a damaged liver, as AST levels (Figure 4) does not support this, vis AST/ALT ratio.

These results establish a link between bioactive metabolites identified in the herbal bitters and physiological uses associated with them. No common identified metabolite was present in the three herbal bitters analysed. Bioactive compounds present in the bitters are Yoyo; 16, living; 12 and Swedish; 8. Living and Yoyo bitters have 5 common bioactive compounds among them.

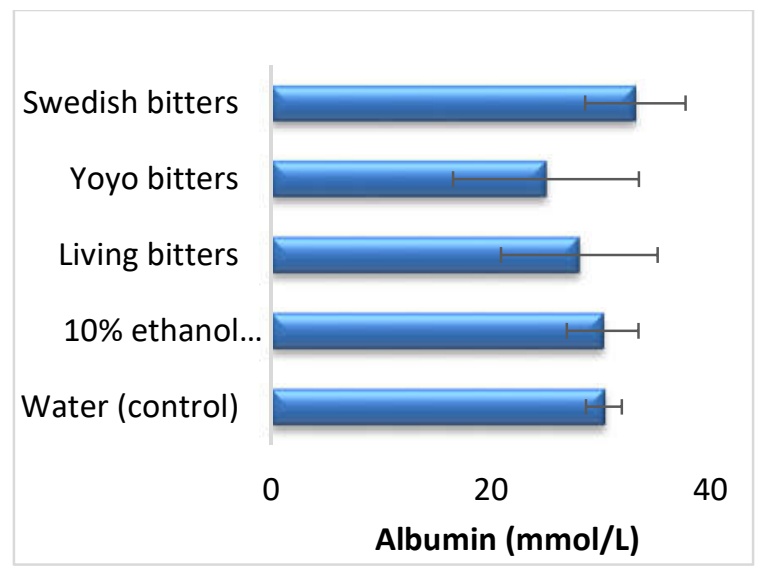

Fig 1. Blood albumin concentrations of test groups on day 40 (Means \pm SEM of 6 rats/group)

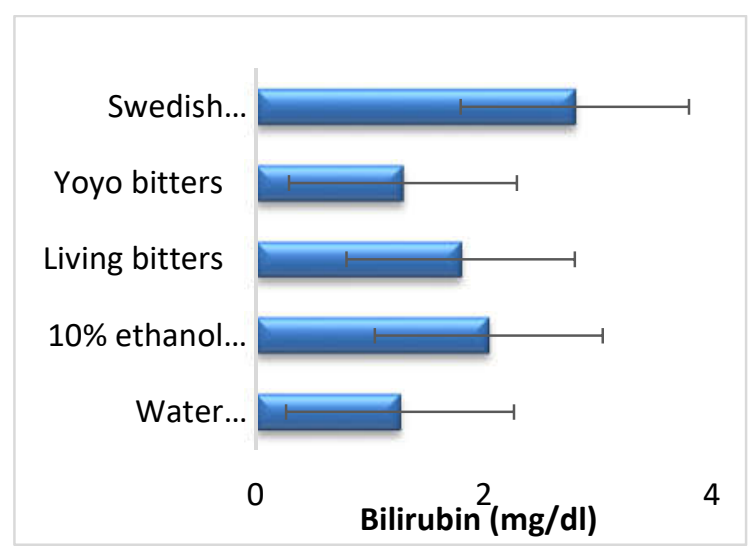

Fig 2: Blood bilirubin concentrations of test groups on day 40 (means \pm SEM of 6 rats/group)

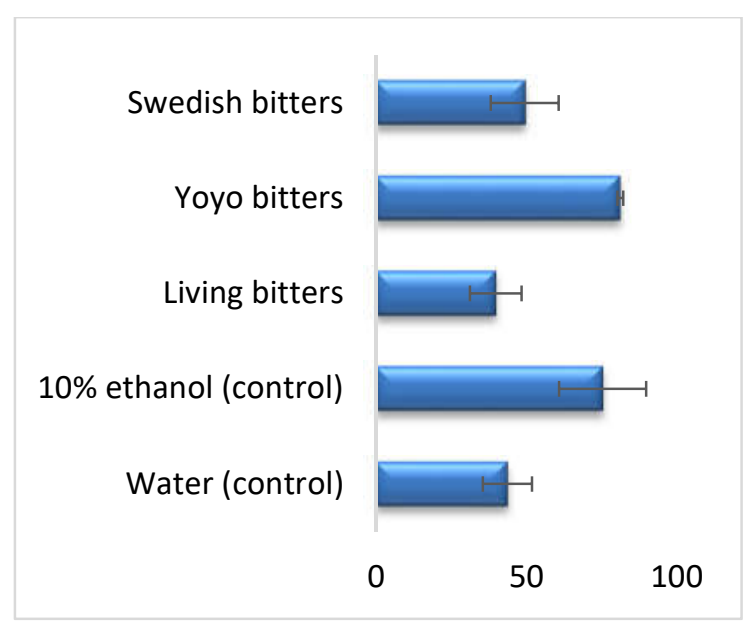

Fig 3 Blood ALT concentrations of test groups on day 40 (means \pm SEM of 6 rats/group) 


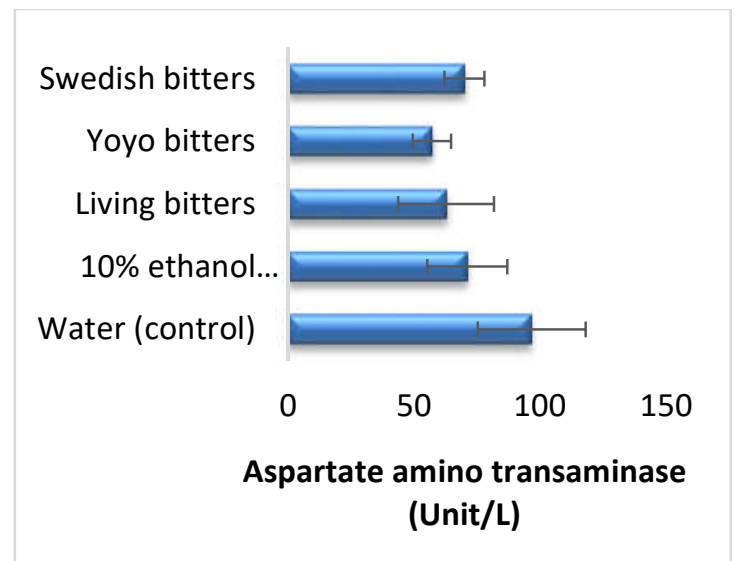

Fig 4. Blood AST concentrations of test groups on day 40 (means \pm SEM of 6 rats/group)

Uses of Swedish bitters includes; menstrual cramps, hemorrhoids, indigestion, detoxification and a boost to the immune system; which may not be unconnected with the presence of 2-Methoxy-4-vinylphenol (a phenolic compound), a documented chemo preventive compound associated with the down regulation (Jeong and Jeong, 2010) of cyclin D1 and E. An overexpression of these two cyclins are correlated with early cancer onset and tumor progression. Another anticancer compound (Cinnamic acid) (Akao et al., 2003; Li et al., 2008; Zhang and Ji, 1991) is also present in Swedish bitters. Cinnamic acid is a member of the auxin (phytohormones) family involved in regulating cell growth and differentiation. A reported mechanism of its action was by prolonging doubling time and inhibiting DNA synthesis of human colon adenocarcinoma cells (Caco-2) (Ekmekcioglu et al., 1998). Some of the uses of this formulation may not be unconnected with the presence of 5Hydroxymethylfurfural, 2,4-Dihydroxy-2,5-dimethyl$3(2 \mathrm{H})$-furan-3-one and 2-Methoxy-4-vinylphenol, all of which are bioactive compounds with numerous reported functions (Table 2). Individually, 2,4Dihydroxy-2,5-dimethyl-3(2H)-furan-3-one and 5Hydroxymethylfurfural are potential anticancer agents (Table 1) and are both present in Yoyo bitters.

Table 2: Bioactive compounds of Swedish, Living and Yoyo bitters as identified using GC-MS

\begin{tabular}{|c|c|c|c|c|c|c|}
\hline \multirow[t]{2}{*}{$\mathbf{S} / \mathbf{N}$} & \multirow[t]{2}{*}{ Bioactive constituents } & \multirow[t]{2}{*}{ MF } & \multirow[t]{2}{*}{ RT } & \multicolumn{3}{|c|}{ Bitters/Percent composition } \\
\hline & & & & Swedish & Living & Yoyo \\
\hline 1 & 1-(2-furyl)-1-propanone & $\mathrm{C}_{9} \mathrm{H}_{10} \mathrm{O}$ & 8.36 & \multirow{3}{*}{ - } & 1.8 & - \\
\hline 2 & 1, 6-anhydro- $\beta$-D-glucopyranose & $\mathrm{C}_{6} \mathrm{H}_{10} \mathrm{O}_{5}$ & 20.88 & & - & 50.0 \\
\hline 3 & 1,1-Dicyanoethane & \multirow[t]{2}{*}{$\mathrm{N}$} & 31.67 & & 16.1 & - \\
\hline 4 & 1,3-Cyclopentadione & & 4.66 & - & - & 1.1 \\
\hline 5 & 2,2-dimethylbutanol & \multirow[t]{2}{*}{$\mathrm{C}_{6} \mathrm{H}_{14} \mathrm{O}$} & 8.70 & \multirow[t]{2}{*}{1.5} & - & - \\
\hline 6 & 2,3-Dihydro-3,5-dihydroxy-6-methyl-4H-pyrene-4-one & & 10.36 & & 10.9 & - \\
\hline 7 & 2,4-Dihydroxy-2,5-dimethyl-3(2H)-furan-3-one & \multirow[t]{2}{*}{$\mathrm{C}_{6} \mathrm{H}_{8} \mathrm{O}_{4}$} & 5.83 & - & - & 1.7 \\
\hline 8 & 2-hydroxy cyclohepta-2,4,6-trienone & & 22.6 & 0.6 & - & - \\
\hline 9 & 2-Hydroxy-2-cyclopenten-1-one & $\mathrm{C}_{5} \mathrm{H}_{6} \mathrm{O}_{2}$ & 4.81 & - & - & 0.7 \\
\hline 10 & 2-Methoxy-4-vinylphenol & $\mathrm{C}_{9} \mathrm{H}_{10} \mathrm{O}_{2}$ & 14.7 & 0.2 & - & - \\
\hline 11 & 2-Methyl-4,5-dihydro-imidazole & $\mathrm{C}_{4} \mathrm{H}_{8} \mathrm{~N}_{2}$ & 4.58 & \multirow[t]{2}{*}{-} & 0.5 & 0.7 \\
\hline 12 & 3,3-Dimethyl-2-butanol & $\mathrm{C}_{6} \mathrm{H}_{14} \mathrm{O}$ & 5.90 & & - & 1.1 \\
\hline 13 & 3,4-dihydroxy-3-cyclobutene-1,2-dione & $\mathrm{C}_{4} \mathrm{H}_{2} \mathrm{O}_{4}$ & 6.23 & \multirow[b]{2}{*}{-} & 0.3 & - \\
\hline 14 & 3-methyl-6-(1-methylethyl)-2,5-piperazinedione & & 8.43 & & 1.6 & - \\
\hline 15 & 5-Acetoxymethyl-2-furaldehyde & $\mathrm{C}_{8} \mathrm{H}_{8} \mathrm{O}_{4}$ & 12.38 & & 0.9 & - \\
\hline 16 & 5-Hydroxymethylfurfural & $\mathrm{C}_{6} \mathrm{H}_{6} \mathrm{O}_{3}$ & 12.29 & & 57.4 & 6.8 \\
\hline 17 & 5-Methyl-2-furancarboxyaldehyde & $\mathrm{C}_{6} \mathrm{H}_{6} \mathrm{O}_{2}$ & 5.10 & - & - & 5.6 \\
\hline 18 & 5-methyl-2-furanmethanol & $\mathrm{C}_{6} \mathrm{H}_{8} \mathrm{O}_{2}$ & 4.96 & - & - & 3.8 \\
\hline 19 & Camphor & $\mathrm{C}_{10} \mathrm{H}_{16} \mathrm{O}$ & 10.5 & 82.9 & - & - \\
\hline 20 & Cinnamic acid & $\mathrm{C}_{9} \mathrm{H}_{8} \mathrm{O}_{2}$ & 18.9 & \multirow[t]{2}{*}{0.3} & - & - \\
\hline 21 & Coumaran & $\mathrm{C}_{9} \mathrm{H}_{6} \mathrm{O}_{2}$ & 12.07 & & 1.6 & 1.7 \\
\hline 22 & Decahydro-2-methylnaphthalene & $\mathrm{C}_{11} \mathrm{H}_{20}$ & 8.57 & \multirow[t]{2}{*}{2.9} & - & - \\
\hline 23 & Decanoic acid & $\mathrm{C}_{10} \mathrm{H}_{20} \mathrm{O}_{2}$ & 30.42 & & - & 0.2 \\
\hline 34 & Furan-2,5-dicarboxaldehyde & $\mathrm{C}_{6} \mathrm{H}_{4} \mathrm{O}_{3}$ & 8.16 & \multirow[t]{2}{*}{ _- } & 1.1 & - \\
\hline 25 & Hexadecanoic acid (palmitic acid) & $\mathrm{C}_{16} \mathrm{H}_{32} \mathrm{O}_{2}$ & 30.91 & & 0.3 & 3.4 \\
\hline 26 & Hexamethyl cyclotrisiloxane & $\mathrm{C}_{6} \mathrm{H}_{18} \mathrm{O}_{3} \mathrm{Si}_{3}$ & 8.06 & \multirow{2}{*}{-} & - & 9.4 \\
\hline 27 & Mono (2-ethylhexyl) phthalate & $\mathrm{C}_{16} \mathrm{H}_{22} \mathrm{O}_{4}$ & 41.95 & & - & 1.9 \\
\hline 28 & Octadecanoic acid & $\mathrm{C}_{18} \mathrm{H}_{36} \mathrm{O}_{2}$ & 35.0 & \multirow[t]{2}{*}{0.6} & - & - \\
\hline 29 & Octamethyl cyclotetrasiloxane & $\mathrm{C}_{8} \mathrm{H}_{24} \mathrm{O}_{4} \mathrm{Si}_{4}$ & 5.99 & & 0.3 & 4.5 \\
\hline 30 & Phthalic acid & $\mathrm{C}_{6} \mathrm{H}_{4}(\mathrm{COOH})_{2}$ & 22.4 & \multirow[t]{2}{*}{$\overline{0.4}$} & - & - \\
\hline \multirow[t]{2}{*}{31} & Squalene & $\mathrm{C}_{30} \mathrm{H}_{50}$ & 46.44 & & - & 3.2 \\
\hline & Total identified & & & 96.8 & 95.2 & 91.4 \\
\hline
\end{tabular}

Conclusion: The three bitters viz; Swedish, Living and Yoyo certainly possess various bioactive components and when administered orally over a period function, as advertised in some cases. The functions/medical 
uses of quite a number of these phytoconstituents are not yet established, the complex interplay between bioactive compounds in herbal preparations and their possible functions remain a grey area.

\section{REFERENCES}

Akao, Y;Maruyama, H;Matsumoto, K;Ohguchi, K;Nishizawa, K;Sakamoto, T;Araki, Y;Mishima, S;Nozawa, Y, (2003). Cell growth inhibitory effect of cinnamic acid derivatives from propolis on human tumor cell lines. Biological and Pharmaceutical Bulletin. 26(7):1057-1059

Akinyemi, O;Dada, E, (2014). In vivo antityphoid activities and proximate analysis of ethanolic leaf extracts of Parquetina nigrescens. Journal of Pharmacy and Biological Sciences. 9(5):115-123

Ekmekcioglu, C;Feyertag, J;Marktl, W, (1998). Cinnamic acid inhibits proliferation and modulates brush border membrane enzyme activities in Caco-2 cells. Cancer Letters. 128(2):137-144

Jeong, JB;Jeong, HJ, (2010). 2-Methoxy-4vinylphenol can induce cell cycle arrest by blocking the hyper-phosphorylation of retinoblastoma protein in benzo [a] pyrene-treated NIH3T3 cells. Biochemical and biophysical research communications. 400(4):752-757

Jimmy, E;Udofia, A, (2014). Yoyo Bitters. A potent alternative herbal drug in the treatment of diabetes. International Journal of Innovative Medicine and Health Science. 2:1-5
Li, Q-F;Shi, S-L;Liu, Q-R;Tang, J;Song, J;Liang, Y, (2008). Anticancer effects of ginsenoside Rg1, cinnamic acid, and tanshinone IIA in osteosarcoma MG-63 cells: nuclear matrix downregulation and cytoplasmic trafficking of nucleophosmin. The international journal of biochemistry \& cell biology. 40(9):1918-1929

Ogbonnia, S;Mbaka, G;Igbokwe, N;Anyika, E;Alli, P;Nwakakwa, N, (2010). Antimicrobial evaluation, acute and subchronic toxicity studies of Leone Bitters, a Nigerian polyherbal formulation, in rodents. Agric Biol JN Am. $1(3): 366-376$

Ojekale, A;Kappo, M;Agbasoro, S;Kazeem, A, (2008). Preliminary study into the long term effects of a hypoglycaemic polyherbal formula (Yem-Kem) on some biochemical parameters in normal rabbits. African Journal of Biotechnology. $7(10)$

Ojekale, AB;Lawal, OA;Lasisi, MO, (2016). Cyathula prostrata: a potential herbal hope for hypertensives, an animal model study and its secondary metabolites assessment via GC-MS. European Journal of Medicinal Plants. 14(2)

Oyevvo, EB, (2013). Sub-chronic Administration of Febi Super Bitters Triggered Inflammatory Responses in Male Wistar Rats. J Med Sci. 13(8):692-699

Zhang, L;Ji, Z, (1991). Synthesis, antiinflammatory and anticancer activity of cinnamic acids, their derivatives and analogues. Yао хие хие bao $=$ Acta pharmaceutica Sinica. 27(11):817-823 